\title{
Determination of suitable timing, frequency and sample size of body condition scoring for herd management in Holstein herds
}

\author{
ERDAL YAYLAK ${ }^{1}$ and YAVUZ AKBAŞ² \\ 'Ödemiş Vocational Schools, Ege University, Izmir, Turkey ${ }^{2}$ Department of Animal Science, Faculty of Agriculture, \\ Ege University, Izmir, Turkey
}

\begin{abstract}
In this study, 11526 body condition scores obtained from 1033 lactations of 696 Holstein cows raised in 17 dairy herds enrolled in Izmir Holstein Breeders Association were used. Several scoring schedules according to days in milk (DIM) such as weekly, bi-weekly, 3weekly, 4-weekly, 6-weekly, 8-weekly and 12-weekly were compared. As a results of this study, it was advised more frequent scoring (weekly) in the first 4-weeks and less frequent scoring (8-weekly) in the mid and the late parts of lactation. Since scoring each cow, especially in large dairies, is time consuming and high labour cost process, a group of cows reflecting group performance can be scored. For example, in the 4-weekly scheme, percentages of cows needed for each DIM group were $5 \%$ of the number of cows available for the first 305 days of lactations. Number of cows to be scored is high at the beginning of lactation and this number decreased towards end of lactation.
\end{abstract}

Keywords: body condition score, frequency, sample size, Holstein Friesian

\section{Zusammenfassung}

\section{Untersuchungen zur Bestimmung geeigneter Zeitpunkte und Frequenzen einer Körperkonditionsbewertung für das Herdenmanagement in Holsteinherden}

Für diese Studie wurden 11526 Körperkonditionswerte von 696 Holsteinkühen mit 1033 Laktationen aus 17 Milchrindherden, welche in der Izmir Holstein Zuchtorganisation erfasst sind, genutzt. Abhängig vom Laktationszeitpunkt d.h. Tage in Milch ab Kälbergeburt wurden unterschiedliche Zeitpunkte wie wöchentlich, 2-, 3-, 4-, 6-, 8- oder 12-wöchentlich verglichen. Zur Beurteilung der Körperkondition erwies sich eine höhere Bewertungsfrequenz in den ersten vier Laktationswochen, eine niedrigere in der Mitte und am Ende der Laktation als nützlich. Da Einzelkuhbewertungen insbesondere in größeren Herden zeitund Kostenaufwendig sind sollten Gruppen abhängig vom Laktationszeitpunkt oder der Leistung gebildet und bewertet werden. Die Anzahl der zu bewertenden Kühe sollte vor allem am Beginn der Laktation hoch sein und kann sich zum Ende der Laktation verringern. Die Bewertung der Körperkondition wird als hilfreich für das Herdenmanagement angesehen.

Schlüsselwörter: Körperkonditionswerte, Frequenz, Stichprobengröße, Holstein Friesian 


\section{Introduction}

Since cow is not capable of consuming as much energy as she requires, high milk producing cows must mobilize large amount of body fat to provide the energy for milk yield and maintenance during early lactation (JONES 1990, LEUTHOLD et al. 1992, 1993). Cows use body tissues and nutrients for milk synthesis by physiological adaptations (KÜHN et al. 2002). Then she loses weight and body condition score. Thus, dairy cows, in general, have a negative energy balance in early lactation. Negative energy balance is getting more intense with high milk yield (STAUFENBIEL et al. 2003). A variable reflecting the energy balance status of cows would be useful for herd management. However, individual food intakes are required to obtain energy balance, but in practice this is not easy application on dairy farms (DE VRIES and VEERKAMP 2000). One of the indicators of energy balance is body condition score (BCS) (EDMONSON et al. 1989). Body fat stores mobilized at the beginning of the lactation are replaced after mid-part of the lactation (EDMONSON et al. 1989, GALLO et al. 1996). Body condition can be followed for each cow from the dry period through lactation. Body condition scoring is a subjective visual evaluation method to assess body fat stores of dairy cows (FERGUSON et al. 1994) and became a common method to estimate the degree of fatness due to easy, quick, repeatable and non expensive method (FERGUSON et al. 1994, DRAME et al. 1999). BCS is used as a management tool in dairy farms and also used to detect the level of carcass composition, milk yields, reproductive performance, and to prevent metabolic disorders and health problems (WILDMAN et al. 1982, JONES 1990, HADY et al. 1994, DRAME et al. 1999, DECHOW et al. 2001).

Mean BCS for each scoring day can be used to detect changes in body fat stores across lactation and the dry periods. Body condition scoring is required in certain frequency to capture changes in condition for each cow. The more frequent scoring is the more reliable. Therefore, in literature different scoring schedules were used as weekly (DOMECQ et al. 1997); 10-daily (PEDRON et al. 1993); bi-weekly (RUEGG and MILTON 1995), 4-weekly (VON EUW et al. 2000); monthly (HADY et al. 1994) and 3-monthly (WILDMAN et al. 1982, GALLO et al. 1996). Furthermore, there are other several scoring programs considering days in milk (DIM) during lactation. DOBBELAAR (1995) reported five strategic periods as 0-60, 61-120, 121-210, end of lactation and dry period while WILDMAN et al. (1982) described five other sub-groups as $0-79,80-159,160-239,239+$ and dry period. In addition to that, there are numerous literature advising scoring at calving, first breeding, pregnancy check and the time before dry period and dry period (JONES 1990, DECHOW et al. 2001). FERGUSON (1996) recommended that scoring could be done in monthly interval or different periods such as at the beginning, mid and late parts of lactation. HADY et al. (1994) reported that BCS intervals of 30 days allowed for precise measurement and the change in BCS over time could be described.

More frequent scoring is more time-consuming works and increased labour cost, especially in large herds. Management decisions on dairies are usually made for a group of cows rather then for individual cow, so that it may not be necessary to examine body condition scores for all cows.

The objectives of this study were

a) to determine a proper sampling scheme for optimal timing and frequency of scoring

b) to estimate the number of cows required (or proportion of cows to be scored) for high precision $(95 \%)$ of BCS means. 


\section{Material and methods}

In this study, 11526 body condition scores collected from 1033 lactation of 696 Holstein cows raised in 17 dairy herds enrolled in Izmir Holstein Breeders Association were used. Cows were scored from January 1999 to May 2001. All BCS were assigned by only one person using the visual technique developed by EDMONSON et al. (1989). BCS were recorded on a scale from 1 (very thin) to 5 (very fat) with increments of 0.25 (total 17 levels). Low scores usually represent thin cows and higher scores represent cows with more subcutaneous fat. Both dry and lactating cows were scored for body condition during herd visits within four weeks intervals.

Frequency of scoring was investigated in herd level instead of individual level. Several sampling schemes were applied according to DIM such as weekly, biweekly, 3-weekly, 4weekly, 6-weekly, 8-weekly and 12-weekly lactation intervals from parturition. The groupings according to DOBBELAAR (1995) and WILDMAN et al. (1982) were also applied (Table 1).

The scale of BCS was considered continuous (even the scores were corrected to the nearest 0.25 point) and normality assumption was satisfied as reported by EDMONSON et al. (1989). This allowed the scores to be examined by parametric statistical methods.

Firstly, univariate analysis was applied to see the changes of BCS among sub-groups for each sampling scheme. Mean BCS differences between adjacent sub-groups from parturition were tested with contrast "repeated" in SPSS. YAYLAK (2003) was focused on modeling of BCS (same data set were used in this study) and analyzed BCS using a model including the factors as herd, cow within herds, calving year, calving season, lactation number, 305-day milk yield, linear, quadratic and cubic forms of DIM, several interaction terms and error. Since the aim was to compare several schemes rather than to find out the best model in this study, cubic model part of the Yaylak's model, which was the best model over linear and quadratic during preliminary analysis of data, was used as

$$
Y=\beta_{0}+\beta_{1} X+\beta_{2} X^{2}+\beta_{3} X^{3}
$$

where $Y$ is the weekly or bi-weekly or 3-weekly BCS and so on, $\beta$ values are the coefficients of the regression model, $X$ is the scoring time in days (DIM). Weekly BCS were estimated from the cubic model in each scheme and weekly differences between observed and estimated BCS were tested using paired t-test. Correlation coefficient between observed and estimated BCS and percentage of squared bias of prediction (PSBP) were calculated as

$$
\frac{\sum_{i}^{n}\left(y_{i}-\hat{y}_{i}\right)^{2}}{\sum_{i}^{n}\left(y_{i}\right)^{2}} \cdot 100
$$

where $n$ is the total number of weeks $(n=70), y_{i}$ and $\hat{y}_{i}$ are the observed and estimated BCS for the 70 sub-groups, respectively.

Number of cows needed for $95 \%$ precision for sub-group's mean BCS was determined for different schemes using two approaches. The first one is the classical approach of COCHRAN (1977) as 


$$
n=\left[\frac{z_{\alpha / 2} \cdot \sigma}{0.25}\right]^{2}
$$

where $z$ is the $z$ value of 1.96 for $95 \%$ precision or confidence, 0.25 is the desired absolute error limit; $\sigma$ is the standard deviation of BCS for the lactation period. Second approach from HADY et al. (1994) was

$$
n=\frac{\left(t^{2} \cdot S D\right) / 0.25^{2}}{1+\left(\left(t^{2} \cdot S D\right) / 0.25^{2}\right) / N}
$$

where $t$ is the $t$ value ( 1.96 due to $n>30$ ) for $95 \%$ precision or confidence, 0.25 is the desired absolute error limit; $S D$ and $N$ are standard deviation of BCS and total number of cows for the lactation sub-group.

\section{Results}

\section{Changes in BCS}

Four weekly mean BCS was 2.88 with standard error of 0.006 . It is changed from 2.45 (week 9) to 3.67 (week 66). Sub-group means differences for BCS in each sampling scheme, were found significant $(P<0.05)$. Numbers of significant mean BCS differences between adjacent sub-groups and the percentages of significant comparisons within total number of adjacent comparisons were given in Table 1.

As sampling interval increases, number of sub-groups decreases. In weekly scheme, there were 71 sub-groups while it was 36, 19 and 7 for bi-weekly, 4-weekly and 12-weekly scheme, respectively. Number of significant comparisons between the adjacent subgroups for weekly scheme was 7 and this figure was changed 5 to 9 for the other schemes with different sampling intervals for BCS. However, percentages of significant comparisons were increased from $10 \%$ for weekly to $89 \%$ for 8 -weekly schemes.

Table 1

Sampling schemes with number of groups for the sampling, significant differences between adjacent sub-groups, number of significant comparisons, correlation coefficient between observed and estimated BCS means under cubic model, probability value $(P)$ for significance of the differences between observed and estimated BCS and their percentage of squared bias of prediction (PSBP) in all sampling schemes

Probenschema bei unterschiedlichen Kontrollzeitpunkten und Gruppenanzahl sowie Korrelationen zwischen beobachteten und geschätzten Körperkonditionswerten

\begin{tabular}{lccccccc}
\hline Sampling interval & Sub-groups & $\begin{array}{c}\text { Adjacent } \\
\text { comparisons } \\
(1)\end{array}$ & $\begin{array}{c}\text { Significant } \\
\text { comparisons } \\
(2)\end{array}$ & $\begin{array}{c}\text { Significant } \\
\text { comparisons } \\
(2 / 1), \%\end{array}$ & Correlation & $P$ & $\begin{array}{c}\text { PSBP } \\
(\%)\end{array}$ \\
\hline Weekly & 71 & 70 & 7 & 10 & $0.923^{* *}$ & 0.978 & 0 \\
Bi-weekly & 36 & 35 & 8 & 23 & $0.916^{* *}$ & 0.866 & 0 \\
3-weekly & 25 & 24 & 7 & 29 & $0.904^{* *}$ & 0.673 & 0 \\
4-weekly & 19 & 18 & 7 & 39 & $0.891^{* *}$ & 0.750 & 0 \\
6-weekly & 13 & 12 & 9 & 75 & $0.861^{* *}$ & 0.761 & 0 \\
8-weekly & 10 & 9 & 8 & 89 & $0.828^{* *}$ & 0.990 & 0 \\
12-weekly & 7 & 6 & 5 & 83 & $0.767^{* *}$ & 0.636 & 1 \\
Dobbelaar & 5 & 4 & 4 & 100 & - & - & - \\
Wildman & 5 & 4 & 4 & 100 & - & - & - \\
\hline
\end{tabular}

** $P<0.01$ 


\section{Sampling frequency}

Increasing sampling interval resulted in an increase for percentage of significant comparisons. The percentages of significant comparison were $100 \%$ for the schemes purposed by WILDMAN et al. (1982) and DOBBELAAR (1995). This high percentage indicates a high success to characterize the lactation periods for BCS. When schemes with different sampling interval were compared, scheme with 8-weekly interval gave the highest success to capture the differences and characterize the related 10 sub-groups of lactation. Eight of nine comparisons between ten sub-groups were significant. Descriptive statistics of BCS for the scheme having 8-weekly interval were given in Table 2 as mentioned also in Table 1 for 8-weekly scheme.

Table 2

Number of cows scored $(N)$, mean BCS levels and significant adjacent comparisons in 8-weekly scheme Anzahl bewerteter Kühe, durchschnittliche Körperkonditionswerte und Vergleich mit dem 8-wöchigen Schema

\begin{tabular}{cccccc}
\hline $\begin{array}{l}\text { Sub-group } \\
\text { order }\end{array}$ & $\begin{array}{l}\text { Time (in week) } \\
\text { to obtain BCS }\end{array}$ & $N$ & Mean BCS & SD & $\begin{array}{c}\text { Significant level of adjacent } \\
\text { comparisons }(P)\end{array}$ \\
\hline 1 & BC & 1013 & 3.458 & 0.018 & BC-8 $(0.000)$ \\
2 & 8 & 1975 & 2.683 & 0.013 & $8-16(0.000)$ \\
3 & 16 & 1873 & 2.505 & 0.013 & $16-24(0.000)$ \\
4 & 24 & 1685 & 2.633 & 0.014 & $24-32(0.000)$ \\
5 & 32 & 1451 & 2.769 & 0.015 & $32-40(0.000)$ \\
6 & 40 & 1170 & 2.944 & 0.017 & $40-48(0.000)$ \\
7 & 48 & 688 & 3.098 & 0.022 & $48-56(0.177) \mathrm{ns}$ \\
8 & 56 & 340 & 3.149 & 0.031 & $56-64(0.000)$ \\
9 & 64 & 173 & 3.337 & 0.043 & $64-72(0.020)$ \\
10 & 72 & 107 & 3.500 & 0.055 & - \\
\hline
\end{tabular}

$N$ number of observations obtained for this sub-group in herd level, SD standard deviation, BC body condition score obtained approximately 2 weeks before calving, ns not significant

Responses from several sampling scheme were compared using weekly BCS estimated from cubic model. Correlation coefficients between observed and estimated BCS from cubic model were given for different schemes in Table 1. These correlation coefficients were generally high $(>0.767)$ and significant $(P<0.01)$. The highest one $(0.923)$ was estimated for weekly scheme while it was the lowest $(0.767)$ for 12 -weekly scheme. However, the differences between observed and estimated BCS were not significant $(P>0.05)$ for all schemes (Table 1). This could be interpreted that cubic model is sufficient to describe the relationship between BCS and DIM. Percentage of squared bias of prediction (PSBP) for BCS from cubic model was generally zero except 12-weekly scheme that had $1 \%$. Consequently, it might be sufficient to use 8 -weekly scheme for the estimation of BCS changes of cows during lactation.

\section{Sample size}

Estimated number of cows needed for $95 \%$ precision for sub-groups of 4 and 12-weekly sampling schemes was given in Table 3. Numbers of cows used for BCS determination in each sub-groups were generally high as compare to the estimated number of cows needed. For example, in 4-weekly scheme, numbers of cows used were changed from 42 
to 1000 . However, only $12-23$ cows are needed for $95 \%$ precision from Cochran's approach, while the estimates from Hady's approach were changed from 17 to 36.

Table 3

Number of cows used $(N)$ and number of cows needed for $95 \%$ precision mean BCS from Cochran's (N1) and Hady's (N2) approaches for different sub-groups in 4 and 12 weekly schemes

Anzahl bewerteter sowie bei $95 \%$ Genauigkeit benötigter Kühe beim Cochran- oder Hadyansatz für unterschiedliche Untergruppen im 4- bzw. 12-Wochen-Schema

\begin{tabular}{|c|c|c|c|c|c|c|c|c|c|c|c|}
\hline \multicolumn{6}{|c|}{ 4-weekly } & \multicolumn{6}{|c|}{ 12-weekly } \\
\hline DIM & $N$ & N1 & $N 2$ & $N 1 / N$ & $N 2 / N$ & DIM & $N$ & N1 & N2 & $N 1 / N$ & $N 2 / N$ \\
\hline $0-28$ & 1000 & 22 & 36 & 0.02 & 0.04 & $0-84$ & 2928 & 21 & 35 & 0.01 & 0.01 \\
\hline $29-56$ & 975 & 18 & 32 & 0.02 & 0.03 & $85-168$ & 2605 & 20 & 35 & 0.01 & 0.01 \\
\hline $57-84$ & 953 & 18 & 33 & 0.02 & 0.03 & $169-252$ & 2099 & 21 & 32 & 0.01 & 0.01 \\
\hline $85-112$ & 920 & 19 & 33 & 0.02 & 0.04 & $253-336$ & 1210 & 22 & 35 & 0.02 & 0.03 \\
\hline $113-140$ & 866 & 20 & 34 & 0.02 & 0.04 & $337-420$ & 445 & 18 & 31 & 0.04 & 0.07 \\
\hline $141-168$ & 819 & 19 & 33 & 0.02 & 0.04 & $421+$ & 175 & 14 & 25 & 0.08 & 0.14 \\
\hline 169-196 & 761 & 22 & 35 & 0.03 & 0.05 & & & & & & \\
\hline $197-223$ & 690 & 20 & 33 & 0.03 & 0.05 & & & & & & \\
\hline $224-252$ & 648 & 22 & 34 & 0.03 & 0.05 & & & & & & \\
\hline $253-280$ & 522 & 23 & 35 & 0.04 & 0.07 & & & & & & \\
\hline $281-308$ & 391 & 21 & 33 & 0.05 & 0.08 & & & & & & \\
\hline $309-336$ & 297 & 20 & 32 & 0.07 & 0.11 & & & & & & \\
\hline $337-364$ & 202 & 19 & 29 & 0.10 & 0.14 & & & & & & \\
\hline $365-392$ & 138 & 16 & 25 & 0.11 & 0.18 & & & & & & \\
\hline $393-420$ & 105 & 16 & 24 & 0.15 & 0.23 & & & & & & \\
\hline $421-448$ & 68 & 16 & 22 & 0.24 & 0.32 & & & & & & \\
\hline $449-476$ & 42 & 12 & 17 & 0.29 & 0.40 & & & & & & \\
\hline $477+$ & 65 & 12 & 19 & 0.19 & 0.29 & & & & & & \\
\hline
\end{tabular}

In general, due to several reasons, number of cows scored is high at the beginning of lactation and this number decreases towards the end of the lactation (Table 3). However dramatic change is not apparent for the number of cows needed. Number of cows needed depends mainly on the amount of variation within the sub-group. However, the percentages of the required number of cows as compared to number of cows used were increased throughout lactation from $2 \%$ to $29 \%$ because late lactation sub-groups have slightly less or similar number of cows estimated as the number for previous sub-groups but less number of cows used. Consequently, small groups require more cows in percentage (29\%) to be scored than the larger groups in size $(2 \%)$. Similar tendency was valid for the other schemes.

\section{Discussion}

Significant differences between the adjacent BCS can be concluded as fast loss or increase of body condition scores during that period. For example in weekly scheme, differences in BCS between first three adjacent week's after parturition can be concluded as fast loss of scores during that period (not illustrated). Regular scoring of body condition with the knowledge of BCS changes during lactation can help to control the natural loss of body reserves at the beginning of lactation and the risk of under or over conditioning cows during later stages of lactation. Negative energy balance of cows 
reaches to maximum level at early lactation (first $1-2$ week) and at least $80 \%$ of dairy cows have negative energy balance for supply milk yield (VILLA-GODOY et al. 1988, BUTLER and SMITH 1989). Therefore about $33 \%$ of milk yield during first month of lactation are supported by body energy reserves of dairy cows (BAUMAN and CURRIE 1980).

The results show that monitoring BCS can be used as a part of the farm management decision system. However, farm managers, consultants and herd health veterinarians need established targets in terms of BCS for lactation periods. Farm manager and/or feeding expert can make groups according to stage of lactation profiles or BCS and milk yield. According to the present results, BCS must be obtained weekly, if possible, during the first 3 or 4-weeks of lactation. After 4-weeks, BCS might be evaluated less frequent such as biweekly scoring two times and then 8-weekly scoring during mid and late lactation. For the purpose, WALLACE (2000) advised seven strategic groups to make good use of body scores. These groups were far-off dry cows, close-up dry cows and fresh cows (1 to 30 DIM), peak milk cows (31 to 100 DIM), mid-lactation cows (101 to 200 DIM), latelactation cows (201 to 300 DIM), and cows due to go dry period (>300 DIM). PARKER (1994) declared six lactation sub-groups as mid of dry period, at the parturition, DIM 45, 60, 180 and 270.

On the other hands, size of herds may affect the scoring periods. In smaller herds, each month, it's the best to score the entire herd (WALLACE 2000). Monthly scoring systems will give a broad picture of herd performance (HADY et al. 1994). However, FERGUSON (1996) affirmed for the herds having problems that body condition scoring may need to be done on a bi-weekly or tri-weekly basis to follow responses to recommendations. Recommendations vary, but to save time scoring cows during some routine events such as calving, post calving exams, first Al, pregnancy checks, and again at dry off is a logical approach. Scoring in large dairies, sufficient number of cows scored is important to reflect the BCS level of the periods and to determine quickly body reserve and nutritional status of cows (HADY et al. 1994).

Based on the variation in BCS and the size of a group, HADY et al. (1994) showed that about $50 \%$ of the cows in a given group need to be scored to obtain an accurate average BCS. If there is a large variation in BCS within a group of cows, then a larger number of cows must be scored to obtain an accurate average BCS. Because of variation in BCS and smaller group sizes, smaller herds may require more than $50 \%$ of cows in a group to be scored, while larger groups may require less than $50 \%$. However, in this study, percentage of cows needed for 4 -weekly schemes was less than $40 \%$ and changed $2-40 \%$ for the $95 \%$ precision (Table 3). For the first 305 day of lactations, needed cow proportions (\%) were generally changed from 1 to $11 \%$ of the cows in the sub-groups. Consequently, it could be said that $5 \%$ of the cows are sufficient for determining BCS in the herd before 200th day of lactation. However, $10 \%$ of the cows should be scored between DIM 200 and 300 . After DIM 300 at least $20 \%$ of the cows are needed to be scored. On the other hand, in those dairy herds where regular recording system was not well established, scoring is more beneficial to control herd management and feeding programs. Thus, it might be possible to improve milk yield and reproduction with reducing health problems using BCS. 


\section{References}

Bauman DE, Currie WB (1980) Partitioning of nutrients during pregnancy and lactation a review of mechanisms involving homeostasis and homeorhesis. J Dairy Sci 63, 1514-29

Butler WR, Smith RD (1989) Interrelationships between energy balance and postpartum reproductive function in dairy cattle. J Dairy Sci 72, 767-83

Cochran WG (1977) Sampling techniques. John Wiley \& Sons Inc, Canada

De Vries MJ, Veerkamp Rf (2000) Energy balance of dairy cattle in relation to milk production variables and fertility. J Dairy Sci 83, 62-9

Dechow CD, Rogers GW, Clay JS (2001) Heritabilities and correlations among body condition scores production traits and reproductive performance. J Dairy Sci 84, 266-75

Dobbelaar P (1995) Body condition of cows Veepro Holland 23, 12-3

Domecq JJ, Skidmore Al, Lloyd JW, Kaneene JB (1997) Relationship between body condition scores and conception at first artificial insemination in large dairy herd of high yielding Holstein cows. J Dairy Sci 80, 113-20

Drame ED, Haznen CH, Houtain JY, Laurent Y, Fall A (1999) Evolution of body condition score after calving in dairy cows. Ann Med Vet 143, 265-70

Edmonson AJ, Lean IJ, Weaver LD, Farver T, Webster G (1989) A body condition scoring chart for Holstein dairy cows. J Dairy Sci 72, 68-78

Ferguson JD, Galligan DT, Thomsen N (1994) Principal descriptors of body condition score in Holstein cows. J Dairy Sci 77, 2695-703

Ferguson JD (1996) Implementation of a body condition scoring program in dairy herds. Feeding and managing the transition cow. The Penn Annual Conference

Gallo L, Carnier P, Cassandro M, Mantovani R, Bailoni L, Contiero B, Bittante G (1996) Change in body condition score of Holstein cows as affected by parity and mature equivalent milk yield. J Dairy Sci $79,1009-15$

Hady PJ, Domecq JJ, Kaneene JB (1994) Frequency and precision of body condition scoring in dairy cattle. J Dairy Sci 77 (1994) 1543-7

Jones GM (1990) Body condition scores for evaluation of nutritional status. Virginia Cooperative Extension Service Dairy Guidelines Publication 404-104, 1-8

Kühn C, Bellmann O, Voigt J, Wegner J, Guard V, Ender K (2002) An experimental approach for studying the genetic and physiological background of nutrient transformation in cattle with respect to nutrient secretion and accretion type. Arch Tierz 45, 317-30

Leuthold G, Müller U, Reinecke P, Brunsch C, Leucht W (1993) The suitability of biochemical parameters of the energy metabolism for the indirect selection on nutrient employment and residual feed intake in dairy cattle. Arch Tierz 36, 299-314 [in German]

Leuthold G, Walter AQ, Reinecke P, Henneberger S, Müller U (1992) Genetic variability of biochemical traits relating to intermediary metabolism in dairy cattle and the suitability of these traits for indirect selection for feed intake and energy balance. Arch Tierz 35, 51-63 [in German]

Parker R (1994) Using body condition scoring in dairy herd management. Ontario Ministry of Agriculture Food and Rural Affairs Order no 94-053 March 1994

Pedron O, Chell F, Senator E, Baroli D, Rizza R (1993) Effect of body condition score at calving on performance some blood parameters and milky fatty acid composition in dairy cows. J Dairy Sci 76 2528-35

Ruegg PL, Milton RL (1995) Body condition scores of Holstein cows on Prince Edward Island Canada: relationships with yield reproductive performance and disease. J Dairy Sci 78, 552-64

Staufenbiel R, Schröder U, Gelfert CC, Panicke L (2003) Body condition and metabolic stability as basis of high milk yield reproductive performance and general health in dairy cows. Arch Tierz 46, 513-526

Villa-Godoy A, Hughes TL, Emery RS, Chapin LT, Fogwell RL (1988) Association between energy balance and luteal function in lactating Holstein cows. J Dairy Sci 71, 1063-72

Von Euw D, Erdin D, Leuenberger H, Tschümperlin K, Künzi N (2000) Estimation of live weight and empty body weight with body measurements body condition and linear type scores in dairy cows. 51st EAAP Ann Meeting (2000) Sess C5.29

Wallace RL (2000) What condition scoring can tell you. Hoard's Dairyman, September 25, 628-9 
Wildman EE, Jones GM, Wagner PE, Boman RL, Troutt HF, Lesch TN (1982) A Dairy cow body condition scoring system and its relationship to selected production characteristics. J Dairy Sci 65, 495-501

Yaylak E (2003) Researches on some physiological and morphological traits of Holstein cows bred in registered herds in Ödemis region. PhD Thesis Ege University Izmir Turkey

Received 20 February 2008, accepted 13 February 2009.

Corresponding author:

Dr. ERDAL YAYLAK

email: erdal.yaylak@ege.edu.tr

Ödemiş Vocational Schools, Ege University, 35760 Ödemiş, Izmir, Turkey 